Does Generosity Beget Generosity?

Alumni Giving and Undergraduate Financial Aid

by

Jonathan Meer, Texas A\&M University

Harvey S. Rosen, Princeton University

The Griswold Center for Economic Policy Studies

Working Paper No. 224, October 2011

Acknowledgements: We are grateful to the Benjamin H. Griswold III, Class of 1933, Center for Economic Policy Studies at Princeton University for support of this research. We have received useful suggestions from Ronald Ehrenberg, Mark Hoekstra, Robin Moscato, and participants in the Bush School Quantitative Workshop. 


\section{Abstract \\ Does Generosity Beget Generosity? Alumni Giving and Undergraduate Financial Aid}

We investigate how undergraduates' financial aid packages affect their subsequent donative behavior as alumni. The empirical work is based upon a rich set of micro data on alumni giving at an anonymous research university, which we call Anon U. We focus on three types of financial aid, scholarships, loans, and campus jobs. A novel aspect of our modeling strategy is that, consistent with the view of some professional fundraisers, we allow the receipt of a given form of aid per se to affect alumni giving. At the same time, our model allows the amount of the support to affect giving behavior nonlinearly.

Our main findings are: 1) Individuals who took out student loans are less likely to make a gift, other things being the same. Further, individuals who take out large loans make smaller contributions as alumni, conditional on making a gift. This effect is unlikely to be due to the fact that repaying the loan reduces the alumnus's capacity to give. We conjecture that, rather, it is caused by an "annoyance effect" - alumni resent the fact that they are burdened with loans. 2) Scholarship aid reduces the size of a gift, conditional on making a gift, but has little effect on the probability of making a donation. Students who received scholarships are also less likely to be in the top 10 percent of givers in their class in a given year. The negative effect of receiving a scholarship on the amount donated decreases in absolute value with the size of the scholarship. Again, we do not find any evidence of income effects, i.e., that scholarship recipients give less because they have relatively low incomes post graduation. 3) Aid in the form of campus jobs does not have a strong effect on donative behavior.

Jonathan Meer

Department of Economics

Texas A\&M University

College Station, TX 77843

jmeer@econmail.tamu.edu
Harvey S. Rosen

Department of Economics

Princeton University

Princeton, NJ 08544

hsr@princeton.edu 


\section{Introduction}

Financial aid to undergraduates from their schools has been growing over time; according to the College Board [2010, p.3], institutional grant dollars per full-time-equivalent undergraduate increased at an average annual rate of about 2.8 percent over the 1999-2000 to 2009-10 decade. At the same time, institutions of higher education have become ever more reliant on support from alumni contributions, which were $\$ 7.1$ billion in 2010 (Council for Aid to Education [2011]). This paper examines one potential linkage between these two trends, the possibility that the financial packages students receive when they are undergraduates affect their subsequent donative behavior as alumni. Indeed, "conventional wisdom among university fund-raisers holds that former scholarship recipients... are among the most dependable donors because they are grateful to the institution and want to lend a hand to the next generation” (Bombardieri [2007]). This intuition is consistent with the literature on gift exchange in charitable giving. For instance, Falk [2007] conducts a field experiment in which potential donors who receive a large gift with their solicitation donate more than those who receive a small gift, who in turn donate more than members of the control group, who receive no gift.

The flip side of this argument is that students who leave college with large loans may feel some resentment and therefore donate less money, other things being the same. As a recent graduate from Boston University said, “I got a great deal with my financial aid, but I'm still paying tens of thousands of dollars. And now they want more money? I think it's just ludicrous” (quoted in Bombardieri [2007]). Alternatively, loan recipients might donate less simply because repaying the loans reduces their disposable income.

We investigate these and related hypotheses using a rich set of micro data on alumni giving at an anonymous private research university, which we will call Anon U. We follow a group of about 13,000 alumni who graduated between 1993 and 2005. The panel nature of the data allows us to examine issues relating to the time pattern of giving, in particular, the frequency with which individuals make gifts. Such questions cannot be addressed by previous studies, which have tended to look at either a single year's worth of data, or have examined average giving over a number of years. In addition, our data provide a more detailed characterization of financial aid 
packages than has been available to previous researchers. In particular, in addition to grants and loan aid, we also have information on earnings from campus jobs.

Section 2 of the paper reviews the relevant literature. Section 3 discusses the data. We present the econometric specification and results in Section 4. Our main findings are: 1) The mere fact of taking out a student loan decreases the probability that an individual will contribute to the university as an alumnus. Further, individuals who take out large student loans make smaller contributions as alumni, conditional on making a gift. Taking advantage of correlates of income that are in our data set, we argue that this negative impact is unlikely to be due to the fact that alumni who took out loans have relatively low disposable incomes. We conjecture that, rather, it is caused by an "annoyance effect" - alumni resent the fact that they received loans rather than outright grants. 2) Financial aid received in the form of scholarships reduces the size of a gift, conditional on making a gift, but has little effect on the probability of making a gift. Students who received scholarships are also less likely to be in the top 10 percent of givers in their class in a given year. Again, we do not find any evidence of income effects, i.e., that undergraduates who received scholarships give less because they have relatively low incomes as adults One possible explanation is that scholarship recipients prefer to give to charities other than their alma mater. Interestingly, among the group of scholarship recipients, subsequent donations increase with the size of the scholarship (although the amounts are still less than for non-grant recipients). This suggests that at least some kind of gift exchange motive is present among scholarship awardees. 3) Aid in the form of campus jobs does not have a strong effect on donative behavior.

Section 5 discusses some alternative specifications of the model in order to assess the robustness of our results. In particular, we allow individuals' responses to the composition of their aid packages to depend on their demographic characteristics. We find some differences across racial groups, but the responses of men and women are about the same. Additionally, and somewhat surprisingly, the effects of having received aid do not change greatly as alumni age. We conclude in Section 6 with a summary and suggestions for future research. 


\section{Previous Literature}

Several papers have used institutional level data to study the link between financial aid packages and subsequent alumni giving. ${ }^{1}$ Ficano and Cunningham [2002] characterize financial aid as the percentage of the cost of attending the institution full time that is rebated in the forms of need based scholarships, non-need based scholarships, and student loans from college funds. They find that more generous need-based scholarships are associated with higher subsequent alumni donations. Baade and Sundberg [1996] include in their model the percentage of students who receive financial aid, along with scholarship and fellowship amounts per student. They find no effect of scholarship aid on alumni giving, and negative effects for the percentage receiving financial aid only for liberal arts schools. While interesting, the results of studies using institutional level data must be regarded with caution because the cultures and histories of different colleges are highly diverse. Hence, unobserved variables such as the style of university governance could be driving both financial aid policy and alumni giving patterns.

An alternative strategy that avoids this problem is to use micro data from a single or several institutions, a tack taken by Clotfelter [2001], Monks [2003] and Holmes [2009]. The impact of financial aid is not the main focus of any of these studies, and the characterizations of individuals' undergraduate aid packages are consequently not very detailed. Clotfelter's model of alumni giving includes only a dichotomous variable indicating whether an individual received financial aid, Monks includes the size of any loans and an indicator for whether they were a "major" or "minor" source of support, and Holmes includes dichotomous variables both for whether the individual received loans or grants. Their substantive results differ across papers and sometimes within the same paper. Clotfelter finds that for some cohorts of individuals, the receipt of needbased financial aid depressed future giving, but for others, there was no statistically significant effect. Monks’ results suggest that recipients of financial aid are more likely to make subsequent donations but loans depress the likelihood of making gifts, while Holmes finds that neither the receipt of grants nor loans affects donative behavior. This is similar to the result of McDearmon and Shirley [2009], whose analysis of online survey data (as opposed to administrative data) suggests that neither financial awards nor student loans affect alumni giving.

\footnotetext{
${ }^{1}$ While the literature on the effect of financial aid on behavior after college is rather sparse, there has been a good deal of literature on the effects of financial aid before college, i.e., on college attendance decisions. See, for example, Dynarski [2000].
} 
Marr et al. [2005] examine the amounts given by the individuals in their sample over the first eight years after they graduated. Their data allow them to include a quite detailed characterization of financial aid packages. They consider amounts of need-based loans, need-based scholarships, merit-based scholarships, and athletic scholarships. They find that loans decrease both the probability and amount of giving, and need-based scholarships have the opposite effect. They enter their variables as step functions, and there is some evidence that the effects of loans and scholarships are nonlinear. Their econometric model does not attempt to take advantage of the longitudinal nature of their data set because so few individuals make contributions in any given year. Rather, their focus is on whether or not the individual made any gift during the eight-year period after graduation. Such averages can mask substantial heterogeneity; someone who gives once during an extended period of time is treated as being exactly the same as someone who makes a donation every year.

Our data set, described below, includes a rich set of information relating to the structure of financial aid packages, including income from on-campus jobs, which has not been studied before. In addition, unlike previous studies, we track a subset of the individuals in our sample over a sufficiently long period of time that we can make at least some inferences with respect to whether the effects of the financial aid package diminish with time. Our econometric procedure takes advantage of the longitudinal nature of the data set, allowing us, for example, to compare patterns of giving rather than just a snapshot of a single year's donations.

\section{Data}

Our data are drawn from Anon U’s administrative archives. The data are proprietary and sensitive, and individuals' names were stripped from the records before being made available to us. Our sample consists of all individuals who graduated between 1993 and 2005. We have each individual's giving history from the year after graduation until 2009. Our unit of observation is a yearly giving opportunity. For example, if an individual has been an alumna for 5 years, she accounts for 5 giving opportunities, starting in the first fiscal year after graduation. Multiple gifts in the same year are summed together. We begin with 142,874 observations, representing 14,382 alumni. We delete 5,175 observations because of missing or unreliable data, leaving 137,699 observations on 13,831 alumni. Of these observations, 84,394 (or 61.3 percent) are associated with a gift. 
At Anon U, eligible students can receive aid in the form of scholarships, loans and campus jobs. About 49.6 percent of the individuals in our sample received any financial aid at all during their time at Anon U. 44.7 percent received some scholarship aid; 40.4 percent received aid in the form of a campus job, and 43.0 percent received loans; 34.8 percent received all three types of aid. ${ }^{2}$ All scholarships are need based; there are no athletic or merit scholarships given by the university. Conditional on receiving a scholarship, the average amount received during a student's undergraduate career is $\$ 71,471$ (s.d. $=\$ 45,921)$.

During our sample period, the average interest rate on student loans was about 7 percent, and the repayment period was 10 years beginning at graduation. ${ }^{3}$ (If a student went directly to graduate school, repayment of the loans was deferred, and the 10 year clock started when graduate school was completed. $)^{4}$ Conditional on receiving a loan, the average amount over the individual's undergraduate career is $\$ 15,633$ (s.d. $=\$ 8,308)$.

Campus jobs typically involved 9 or 10 hours of work per week for the 30 weeks of the academic year; the average amount of money from campus jobs is $\$ 9,544$ (s.d. $=\$ 4,429) .{ }^{5}$ This figure includes remuneration from both positions arranged by the financial aid office as well as other jobs such as research assistants. ${ }^{6}$ Appendix Table A1 shows the average amounts per alumnus of scholarship, job, and loan aid during students' four years, measured in thousands of dollars, conditional on each source of aid being positive. The unit of observation for this table is a yearly giving opportunity as defined above.

\footnotetext{
${ }^{2}$ These figures include aid that came from sources external to the university. Our data do not allow us to distinguish between funds received from the university and external funds. However, over 93 percent of scholarship aid comes from university sources.

${ }^{3}$ In 2001, Anon U moved to a no-loan policy; the class of 2005 was the first to have all four undergraduate years under this policy. Financial need was fully met by grants and campus jobs and aid that previously would have come in the form of loans came as grants instead. However, students were still able to take out loans to meet costs in excess of their calculated financial need; thus, some positive loans are still recorded for those classes, though their prevalence is much lower. Since the policy is relatively recent, it is difficult to get precise estimates of its effects on alumni giving, particularly because they are not distinguishable from cohort effects. A comparison of giving behavior in the first 5 years after graduation before and after the policy shows very little effect. However, given the problems with identifying the impact and the small number of affected cohorts in our sample, one cannot make too much of this finding.

${ }^{4}$ The average loan repayment during the 10-year period for a member of the class of 2001 was about \$166 per month.

${ }^{5}$ The median values for loan, scholarship, and job aid, respectively, are $\$ 15,961 ; 69,503$; and $\$ 10,544$.

${ }^{6}$ Income from campus jobs not arranged by the financial aid office is recorded only for aid recipients; a student not on financial aid who worked as, say, a research assistant would not have his or her income reported here. Information on off-campus jobs is not available.
} 
We also have information on the alumnus's undergraduate extracurricular activities, post graduate education, residence, whether he or she is married to another graduate of Anon U, SAT scores, academic honors, ethnicity, type of high school, summary evaluations made by the Admissions Office during the application process, major and minor course of study, and grade point average. Summary statistics for these other variables are included in Table A1 as well.

\section{Econometric Specification and Results}

\section{$\underline{4.1 \text { Econometric Specification }}$}

Previous empirical work on the determinants of giving suggests that variables can have different effects on the decision whether or not to donate - the extensive margin — than on the decision how much to donate, conditional on making a gift — the intensive margin. ${ }^{7}$ A statistical model that allows for this possibility is therefore needed. We assume that each alumnus first chooses whether or not to make a gift and then, conditional on making a gift, decides how much to donate. Following Huck and Rasul [2007], a natural specification is a hurdle model. In our context, the first step in the implementation of the hurdle model is to estimate a linear probability model for whether or not the individual makes a gift. ${ }^{8}$ The second step is to use ordinary least squares on the positive observations to analyze the decision about how much to give. In order to make causal inferences from the second-stage estimates, one must assume that the second stage is conditionally independent of the first. We discuss this further below. We correct for correlation among the error terms for any given individual with a clustering procedure.

An alternative two-step procedure, suggested by Heckman [1979], can also be used to estimate the amount of giving, conditional on it being positive. Heckman's model augments the OLS equation in the second stage with the inverse Mills ratio. There is some controversy in the literature with respect to which estimator is superior (Leung and Yu [1996]); hence, a sensible approach is to estimate the model both ways. We show below that our substantive results are essentially unchanged when we use Heckman's method.

\footnotetext{
7 Thus, for example, it would not be appropriate to use a Tobit model, which imposes the constraint that the marginal effect of a given variable on the probability of giving and the marginal effect on the amount given are the same up to a constant of proportionality.

${ }^{8}$ It is more common to use a probit model for this first stage. However, the interpretation of the marginal effects in the presence of quadratic terms and interactions is less intuitive in non-linear models than in the linear probability model, so we prefer the latter. This issue is described in more detail below.
} 
As is typical, a few relatively large gifts account for a disproportionate amount of Anon U's donations. For example, in our analysis sample, the top one percent of gifts in 2009 accounted for 50.8 percent of total giving. These large gifts are critical to the university, so it is important to determine whether financial aid packages affect the likelihood of such gifts. We therefore also use a linear probability model to estimate the probability that the alumnus is a “class leader” in a given year, where a class leader is defined as an individual who donated an amount greater than or equal to the $90^{\text {th }}$ percentile of gifts in his or her class. Given that, by construction, the mean of the left hand side variable in this model is about 0.10 , the linear probability model might not be appropriate. In Section 5 below we show that our substantive results are very much the same when we estimate the class leader model using a probit. Another issue relates to the fact that our data contain a few very large outliers. For example, there are 11 gifts greater than $\$ 100,000$ in our sample. To address this issue, we use the logarithm of the amount of giving on the left hand side of the equation for the intensive margin. As an additional check to make sure that outliers are not driving our results, we estimate the OLS equation with the top one percent of the observations eliminated. In Section 5 we show that the substantive results with respect to the impact of financial aid are unchanged.

A major issue is how to characterize the structure of undergraduates' financial aid packages. The conjectures about the possible effects of financial aid discussed above suggest that we need a specification that allows us to address the following questions: does the mere receipt of a particular form of aid have an effect on giving; what is the marginal effect of receiving additional aid of a given type; and what is the overall effect of a given aid package? With that in mind, we adopt a somewhat novel modeling strategy, and include both a dichotomous variable that takes a value of one if the individual received any aid of a given type, as well as a quadratic in the amount of that kind of aid.

The dichotomous term allows for the possibility that the receipt of a particular form of aid per se affects subsequent giving. Fundraising professionals are keenly aware of this mechanism. The Vice-President for Development at Boston University, discussing it in the context of the impact of college loans on giving behavior, said that he was concerned about a "psychological debt burden. Whether your debt is $\$ 200$ or $\$ 200,000$, you don’t tend to write checks as long as you have it” (Bombardieri [2007]). It is also possible that students who took out loans have lower family incomes than their peers, or perhaps developed less of an affinity for Anon U when 
they were undergraduates. We discuss the interpretation of the coefficient on the indicator variable in more detail below.

The quadratic terms allow for nonlinearity in the impact of the amount of the form of aid. ${ }^{9}$ We choose a quadratic over a logarithmic function for two reasons. First, for many individuals, the amount of aid is zero. Second, the interesting question facing university administrators is generally how given dollar amounts of different types of financial aid (as opposed to a given percentage changes) affect future giving, and the quadratic specification facilitates such comparisons. A related reason for using levels rather than logs is that it allows a direct test of the hypothesis that alumni react similarly to the same amount of undergraduate aid that comes in different forms (Avery and Hoxby [2004]).

In addition, we include on the right hand side a series of variables about each alumnus that have been shown in previous studies to exert an important influence on alumni giving. ${ }^{10}$ These include years since graduation, gender, ethnicity, SAT scores, ranking of the candidate by the admissions office when they applied to Anon U, course of study, and post-baccalaureate education. The literature also shows that alumni giving is heavily influenced by the affinity that they develop for their schools as undergraduates. Participation in varsity sports and membership in fraternities are two ways in which such affinities develop (Clotfelter [2003], Monks [2003]); we include variables relating to these activities. The model also includes time effects, class effects, and location effects. The year effects reflect the impacts of the business cycle, the stock market, and so on. ${ }^{11}$ The year effects also account for the size of Anon U's fundraising staff and the amount of its fundraising expenditures, which vary from year to year. The class effects control for common influences on alumni in the same class, such as the political milieu when they were undergraduates, the presence of certain professors or administrators, and so on. Summary statistics for these variables are recorded in Table A1.

Unfortunately, our data include no direct information on income, an important determinant of alumni giving (Shulman and Bowen [2001, p. 404]). To address this issue, we begin by noting that a number of the variables in our basic specification are correlated with the individual's income, including gender, ethnicity, college major and grade point average, advanced de-

\footnotetext{
${ }^{9}$ Adding a cubic term did not significantly improve the explanatory power of the equation.

${ }^{10}$ See, for example, Cunningham and Cochi-Ficano [2002], Shulman and Bowen [2001], Lara and Johnson [2008], and Holmes [2009]).

${ }^{11}$ Bristol [1991] emphasizes the role of the stock market and Ehrenberg and Smith [2001] document the importance of macroeconomic conditions.
} 
grees, years since graduation, and location. In addition, as noted below, we augment the basic model with a number of variables that are closely related to permanent income, including the sector in which the individual works, inter alia, and find that our substantive results are not sensitive to their inclusion.

\subsection{Results}

\subsubsection{Probability of Giving}

Table 1 shows the effects of the financial aid variables on the probability of making a gift. For each type of aid, we exhibit the estimated coefficients and standard errors for both the linear and quadratic terms, as well as for the dichotomous variable indicating whether the individual received that form of aid at all. In addition to the financial aid variables in the table, the models include the other right hand side variables mentioned in the previous section, which are suppressed for brevity.

To begin, consider the results for loans in the first panel. The coefficient of -0.0357 on the dichotomous variable Any Loan Aid in the first column means that the receipt of a loan in itself lowers the probability that an alumnus makes a gift by about 3.6 percentage points. Given that the mean rate of giving is about 62 percent, it would seem fair to characterize this as a meaningful although not huge effect.

The positive linear term and negative quadratic term imply that, in absolute value, the negative effect on the probability of giving first decreases and then increases with the amount of the loan; indeed, when the function reaches its maximal value (when loans are around $\$ 13,000$ ), the overall effect is a much weaker, -0.88 percentage points (s.e. $=1.12$ percentage points). The negative quadratic term then begins to dominate and by the time the loan amount is about $\$ 23,000$, the effect is once more significantly different from zero at the 5 percent level. Essentially, receipt of small or large loans reduces the probability of giving, while moderatesized loans have little effect. While we cannot definitively state what is driving these results, a possible explanation is that the annoyance effect of small loans is diminished by gratitude for moderate amounts of aid, while large loans feel like a burden.

One potential reason that student loans reduce the likelihood of making a gift is that students who took out loans subsequently have lower incomes than other alumni, perhaps because they come from families with relatively low incomes, and have less wealth as well as fewer family connections to help them professionally. It follows that to the extent donations to Anon U 
are a normal good, alumni who took out loans will be less likely to make donations. In other words, if loan aid as an undergraduate is correlated with income as an alumnus, then the omission of income from the right hand side might bias the coefficients on loan aid (and other kinds of aid as well). ${ }^{12}$ While we do not have explicit measures of income in our data, we do have several variables that are correlated with income. Specifically, for a subset of our alumni $(114,108$ observations, representing 11,124 alumni), we have information that is closely related to permanent income, the fields in which they work. The fields of education, finance, health care and law are highly represented. The complete distribution of fields across the sample is available upon request. ${ }^{13}$ If income effects are behind the estimated effects of the financial aid variables, then when these correlates of income are included in the model, the coefficients on the financial aid variables should change.

The results when the model is estimated with the field variables are shown in the second column of Table $1 .{ }^{14}$ A comparison with the estimates for our basic model in the first column indicates that they are essentially unchanged. This is consistent with the notion that income effects are not responsible for our results on the impact of loan aid.

To investigate this issue further, we take advantage of the fact that we have information on ZIP code, another correlate of income. We re-estimate the basic model including a dichotomous variable for each three-digit ZIP code. ${ }^{15}$ The results, which are in the third column, are not substantively different from those in Column (1) either. ${ }^{16}$

The starting point for our final check for the presence of income effects is the wellknown observation that the incomes of children and their parents are positively correlated. (See, for example, Behrman and Taubman [1990].) Presumably this correlation is stronger for relative-

\footnotetext{
${ }^{12}$ A related possibility is that repayment of loans diminishes disposable income, which also could reduce donations. We present evidence below that this phenomenon is unlikely to explain our findings.

${ }^{13}$ Due to lack of reliable data regarding the start- and stop-dates of occupation and field, these variables indicate whether the alumnus was ever involved in that field or occupation, rather than whether they are involved during the particular year of observation.

${ }^{14}$ In order to benchmark this exercise, we estimated the basic model (i.e., the model without the occupation and field variables) using the smaller sample that includes only the observations with the occupation and field variables. These results, too, were substantively the same as those in Column (1).

${ }^{15}$ For alumni living abroad, we include indicators for their country.

${ }^{16}$ A related approach is to include ZIP-code-level measures of income as regressors instead of three-digit ZIP code dichotomous variables. Implementing this strategy is difficult because income data are unavailable for some areas and we lack a consistent income data on a yearly basis. Nevertheless, we obtain median income data from the 2000 Census and the 2008 IRS Statistics of Income and, separately, map them into each alumnus's ZIP code in each year. While these income variables are statistically significant in the expected direction, neither variable's inclusion has a substantial effect on the coefficients on the financial aid variables. Full results are available on request.
} 
ly young individuals, such as the members of our sample, the oldest of whom are about 38 years old at the end of the sample period. Because aid recipients need to submit evidence of their financial need, we know parental income for alumni who received financial aid as undergraduates. While this is clearly not a random subset of our analysis sample, it is of some interest to see whether the inclusion of parental income for members of this group affects our conclusions with respect to the impact of financial aid. ${ }^{17}$ To construct a benchmark for this analysis, we begin by re-estimating our basic model from Column (1) for this sample, and then augment the model with parents' income. In results available upon request, we find that the coefficients on the financial aid variables are not materially affected. Given the particular nature of this sample, and that parental income is only a proxy for the alumnus's income, we cannot argue too strongly that this exercise rules out the presence of income effects; nevertheless, the preponderance of the evidence suggests that such effects are not driving our results.

We turn next to the results for scholarships in the second panel. The intercept, linear, and quadratic terms in Column (1) are all very small in magnitude and imprecisely estimated. One cannot reject the hypothesis that scholarship aid has no effect on the likelihood of making a donation. Looking across the columns, we see that when we include our additional correlates of income, the substantive results do not change-income effects do not appear to be behind the results.

The last panel has the results for campus jobs. The intercept suggests that receiving this form of aid per se has no discernible impact on the probability of making a gift. The amount of aid from campus jobs has a small negative effect (roughly 0.58 percentage points per thousand dollars) on the probability of giving until about $\$ 7,500$ of aid, at which point the positive quadratic term dominates; the effect on giving at this point is a statistically significant but relatively small -0.031 (s.e. $=0.014)$. Aid through campus jobs does not appear to be an important determinant of the likelihood of making a contribution.

\subsubsection{Amount of Giving}

Table 2 shows the estimates for the log of the conditional amount of giving. The first panel indicates that while none of the individual coefficients on aid from loans is significant, the set of loan variables is jointly significant at $p=0.002$. The point estimate of the intercept for

\footnotetext{
${ }^{17}$ For most of the analysis sample, we have the students' ZIP codes at the time of application to Anon U, a variable that is correlated with family income. The inclusion of indicators for family three-digit ZIP code did not materially affect the estimates of the coefficients on the financial aid variables.
} 
loans, -0.0679 , implies that the receipt of loan aid reduces donations by about 6.6 percent. The negative linear term dominates over the entire range of loan values, and the overall (negative) effect becomes statistically significant at around $\$ 3,000$ of loans. As discussed above, one possible explanation for this phenomenon is that alumni who took out larger loans as undergraduates have relatively low incomes. However, as was the case in Table 1, a look across the columns indicates that augmenting the model with various correlates of income has little effect on the estimates, so income effects are unlikely to be at work.

In the second panel of Table 2, which looks at the impacts of scholarships, the striking result is the coefficient on Any Scholarship Aid, which indicates that the receipt of a scholarship in itself lowers giving by about 18 percent, an effect that is precisely estimated. The negative effect of receiving a scholarship per se is attenuated by the positive though imprecisely estimated linear term. Indeed, at the conditional mean of $\$ 71,000$, the estimated decrease is only half as large, -0.092 (s.e. $=0.043$ ). It becomes insignificantly different from zero (though still relatively large in magnitude) at around $\$ 90,000$ of scholarship aid, and at the conditional $99^{\text {th }}$ percentile of scholarship aid, $\$ 170,000$, the effect is -0.045 (s.e. $=0.071$ ). Thus, larger scholarships are associated with negative, though smaller in absolute value, effects on the size of donations conditional on giving.

In the third panel, we see that aid from campus jobs does not have a statistically discernible effect on the amount of giving.

\subsubsection{Class Leadership}

Table 3 shows the estimates for class leadership. To put these figures in perspective, recall that by construction, the mean value of the probability of being a class leader is about 0.10 . Hence, the point estimate of the loan intercept in Column (1) of the first panel, 0.9 percentage points, is substantial, although imprecisely estimated. The quadratic term is minuscule, and the linear term suggests that each thousand dollar increase in loans reduces the probability of being a class leader by about 0.07 percentage points. While this effect is extremely small on the margin, the overall effect of loans becomes statistically significantly different from zero at around \$6,000 of loan aid.

The effects of receiving scholarship aid on the likelihood of being a class leader are in the second panel. The estimate of the intercept in Column (1) is large, about negative 3.3 percentage points, and precisely estimated. But at the conditional mean of scholarship aid, one cannot reject 
the hypothesis that the effect on being a class leader is zero, though the point estimate is still fairly substantial; the overall effect is -0.014 with a standard error of 0.009 . In the third panel, we see that aid from campus jobs has no discernible effect on the probability of being a class leader. As was the case in Tables 1 and 2, a glance across columns indicates that the results are not sensitive to the addition of variables that are correlated with income.

\subsection{Interpreting the Results}

We begin with the results for loans. The mere fact that an individual took out a student loan reduces both the probability of making a gift and its size, conditional on making a gift. This finding is consistent with the belief of development professionals, mentioned above, that taking on debt per se creates a kind of psychological burden that is independent of the amount of the debt.

We have argued that this finding is unlikely to be due to the fact that undergraduates who took out loans subsequently have lower incomes than their classmates. Another observation consistent with this notion is that the intercept term in the model for the probability of making a gift is negative, and dominates the positive linear term for relatively small loans. In short, smaller loans have a more pronounced negative effect on giving than medium-sized loans, though large loans depress giving on both the intensive and extensive margins. This nonlinear relationship is difficult to reconcile with the notion that income effects are driving our results.

Another possible explanation for the negative effect of loan aid on the probability of making a gift is that loan recipients felt excluded from the majority campus culture when they were undergraduates; hence, their affinity for Anon $U$ is lower. To investigate this possibility, we begin by noting a robust finding in the literature, that individual who participate in fraternities/sororities and varsity sports develop stronger affinities to their colleges, ceteris paribus. (See Clotfelter [2003] and Monks [2003].) If so, the negative effect of loans on giving should be less in absolute value for individuals who were involved in these activities, other things being the same. We augmented our basic models from the first columns of Tables 1, 2, and 3, respectively, with a set of interactions between the financial aid variables and both participation in fraternities/sororities and participation in varsity athletics. The interaction terms were neither individually nor jointly significant. Hence, the negative effect of loans on the probability of making a gift does not appear to be due to the fact that loan recipients were somehow alienated from the campus culture, at least to the extent the majority culture can be characterized by these measures. 
A final possibility is that there is an "annoyance effect" associated with having to pay back loans. Given that the results do not seem to be driven by income or ties to the majority social culture, it is difficult to put forward an explanation other than this psychological burden, mentioned above. That is, loan recipients resent the fact that their aid came in the form of loans rather than grants, and consequently, give less to Anon U.

Turning next to the scholarship results, it is again tempting to attribute the negative effects in Tables 2 and 3 to income effects, which could come about if scholarship recipients have lower incomes than their classmates, and this situation persists after graduation. We have already argued, however, that this is unlikely to be the case. Another problem with an incomeeffect interpretation relates to the observation that the negative effect of receiving a scholarship falls (in absolute value) with the size of the scholarship. Given that scholarships at Anon U are entirely need-based, this means that scholarship students from lower-income families give more than those from higher-income families, ceteris paribus. To the extent that children's incomes are related to their parents' incomes, then if income effects were driving the results, we would expect just the opposite.

Another conjecture is that scholarship recipients might have felt alienated from the majority culture at Anon U, and hence developed less of an affinity for the institution. However, just as was the case for loan recipients, we find no evidence that alumni who are likely to have developed relatively strong affinities to the institution react differently to the receipt of scholarships than other aid recipients. Moreover, one would expect lower affinity to be reflected in a lower probability of giving, not just a smaller amount conditional on giving. Hence, we are inclined to discount this explanation.

How, then, can we account for the negative effects of scholarships on subsequent giving? One possibility is that scholarship recipients might be targeting their donations to other institutions that extend grant aid to students who want to attend college, such as Scholarship America or the United Negro College Fund. Of course, given that we have no information on alumni's other charitable donations, this notion remains conjectural.

It is tempting to argue that because scholarship recipients give less than others, one can reject the hypothesis that they want to "give back." However, the negative impact on the conditional giving to Anon $U$ falls as the amount of the scholarship increases; that is, those who 
received more generous aid as undergraduates give more as alumni, conditional on making a gift. In this limited sense, then, our data are consistent with the gift exchange hypothesis.

\section{Alternative Specifications}

In this section we estimate several alternative specifications of the model in order to assess the robustness of our results.

\section{$\underline{5.1 \text { Outliers }}$}

As is the case at most universities, a few large gifts account for a disproportionate share of total donations to Anon U. As noted earlier, the top one percent of positive gifts in our sample accounted for about half of the total in 2009. This raises the possibility that our results for amounts given in Table 2 are being driven by just a few observations. Our use of logs for the left hand side variables attenuates the impact of outliers, but as another check, we re-estimate the model for amounts given deleting the top one percent of donations in each column from the sample. When we compare these results, available on request, to their counterparts in Table 2, we see that the signs and magnitudes are similar. Hence, outliers do not appear to be driving our results with respect to giving on the intensive margin.

\subsection{Demographic Differences}

Previous empirical research indicates that various aspects of altruistic behavior can differ substantially by demographic group. (See, for example, Andreoni and Vesterlund [2001], Andreoni [2005], and Meer and Rosen [2009].) This raises the possibility that the impact of financial aid might as well. We therefore investigated how our parameter estimates vary by race, gender, and age. To do so, we augmented our basic models from the first columns of Tables 1

through 3 , respectively, with a series of terms interacting the financial aid variables first with the indicator variables for race, then with gender, and finally with age.

The detailed results are presented in the Appendix. The main substantive findings can be summarized as follows:

\subsubsection{Race}

One cannot reject the joint hypothesis that the interactions between the race and financial aid variables are zero. However, some of the interaction terms are individually significant. For instance, the effect of loans on the probability of giving is different for black alumni than other ethnic groups; the linear term is negative while the intercept is positive (the latter is significant at 
$\mathrm{p}=0.08)$. Receiving a scholarship does not have any substantial effect on the size of a gift for Asian alumni. With a few other exceptions, there is little difference across races in the effect of financial aid on alumni giving.

\subsubsection{Gender}

The interaction terms between gender and the financial aid variables are jointly significant for the case of scholarship aid in the model for giving on the extensive margin; otherwise, they are not. The most striking difference is that the negative effect of receiving a scholarship is especially pronounced for alumnae, particularly on the probability of being a class leader.

\subsubsection{Age}

For purposes of examining the impact of age on the response to financial age packages, we create a dichotomous variable that takes a value of one if an alumnus graduated 10 or more years ago and zero otherwise, and interact it with our financial aid variables. Our sample for this specification consists only of individuals who graduated in 1999 or earlier, whose giving behavior we observe both before and after the 10-year mark. One cannot reject the joint hypothesis that the interactions between the financial aid and age variables are zero. This result might be a bit surprising. One could imagine, for example, that any gift exchange motive associated with being a scholarship student could either increase (because of nostalgia) or decrease (because of forgetfulness) with age. Similarly, one might conjecture that any negative feelings associated with having to pay back loans might be less after the loans are paid off. However, we find no evidence that the effect of financial aid packages on future giving depends on how long it is since the alumnus graduated. The "annoyance effect" associated with receiving loans appears to persist beyond the repayment period.

This finding also relates to our previous discussion of whether our results on the impact of loans are due to income effects. We focused on the possibility that individuals who received loan aid have lower incomes as alumni. But an income effect could also arise if the repayment of a loan reduces an individual's disposable income, ceteris paribus. However, if this were the case, we would expect the negative effect of loans to disappear or at least be attenuated after they are paid off. We find no statistically significant difference in the impact of loan aid on the donative behavior of individuals who have been out of school for more than ten years (and have generally paid off their loans) and those who are younger. 


\subsection{Alternative Econometric Specifications}

We have used the convenient linear probability model to estimate the equations for the dichotomous left hand side variables, DidGive and ClassLeader. As is well-known, a possible problem with the linear probability model is that the predicted values may be outside the range zero to one, which is especially likely to be an issue when the mean of the variable is close to zero or one. For DidGive, whose mean is about 0.61 , this is unlikely to be an issue. ${ }^{18}$ In fact, when we estimated the basic model of Column (1) in Table 1 using a probit model, we found essentially identical average marginal effects.

Given that, by construction, the mean of ClassLeader is about 0.10 , the problem is potentially a greater concern for those estimates. When we estimated the ClassLeader model of Column (1) in Table 3 using a probit, we found the following average marginal effects: -0.00092 (s.e. $=0.00084)$ for loans, 0.00042 (s.e. $=0.00022)$ for scholarships, and -0.00115 (s.e. $=$ 0.00151) for campus jobs. These are not dissimilar to the average marginal effects calculated from the model in Column (1) of Table 3: -0.00072 (s.e. $=0.00064$ ) for loans, 0.00028 (s.e. $=$ 0.00013 ) for scholarships, and -0.00039 (s.e. $=0.00106$ ) for campus jobs.

Another econometric issue relates to the use of the hurdle model. An alternative estimator augments the OLS equation for the amount given with the inverse Mills ratio generated by the first stage probit (Heckman [1979]). This model explicitly allows for correlation between the errors in the first and second stage equations. The econometric literature indicates that the desirability of this estimator relative to the hurdle model is unclear. In particular, Leung and Yu [1996] observe that even if the errors in the true model are correlated, the hurdle model may, under certain circumstances, yield better estimates. Also, in the absence of variables that can be excluded from the second stage but still affect the probability of giving, which is our situation, identification comes entirely off of functional form assumptions.

In any case, it seems sensible to re-estimate the model using Heckman's approach to see if the substantive results are affected. They are not. For instance, using the selection model, the effect of receiving a loan on the likelihood of making a gift is -3.7 percentage points, and the effect on the conditional size of the gift is -6.58 percent. The comparable results from our basic specification are -3.6 percentage points and -6.56 percent, respectively. The other variables are

\footnotetext{
${ }^{18}$ Fewer than one percent of the predicted values are outside the range zero to one.
} 
similarly close in magnitude. Hence, our results are robust with respect to this change in econometric specification.

\section{$\underline{\text { 6. Conclusion }}$}

College and university fundraisers are justifiably interested in the impact of undergraduate financial aid packages on future gift-giving by alumni. Do students who receive loans or who need to take campus jobs give less in the future because they are resentful? Do scholarship recipients donate more because they want to "give back?" We have analyzed micro data from a selective research university to address these questions. We find that the mere act of taking out a student loan decreases the probability that an individual will contribute to the university as an alumnus, and that large student loans reduce future donations, conditional on making a gift. Financial aid received in the form of scholarships reduces the amount of alumni giving, conditional on making a gift, but has little effect on the probability of making a gift. Students who received scholarships are also less likely to be in the top 10 percent of givers in their class in a given year. We find no evidence that the negative effects of loans and scholarships on subsequent giving are due to aid recipients having lower post-graduation incomes than their peers. Nor is there any evidence that scholarship recipients give less because they did not feel part of the majority culture on campus when they were undergraduates. We conjecture that their charitable giving might be focused on organizations other than their relatively wealthy alma mater.

Our results provide mixed evidence for the gift exchange model. As just noted, it does not appear that out of gratefulness, alumni who received financial aid give back to the university more generously than alumni who received no aid. Indeed, scholarship recipients give less than their classmates, ceteris paribus. However, among the group of scholarship awardees, those who received larger grants make larger donations as alumni, providing some evidence for a gift exchange motive. In any case, to the extent our findings generalize, universities should not expect that generous financial aid will pay for itself through larger donations in the future. Of course, there remain myriad reasons to maintain these policies apart from the financial status of the university.

An important qualification is that our results do not necessarily reflect the causal impacts of financial aid. Rather, despite the fact that our statistical model controls for a variety of demographic and family background characteristics, financial aid recipients might differ from 
their peers in ways that affect the affinity they develop for their alma mater. Indeed, the most important channel through which major changes in financial aid policy affect alumni giving might be the impact on the composition of the student body. Put another way, our results are best thought of as estimates of local effects, that is, the impacts of modifying the parameters of an existing financial aid program rather than rather than implementing an entirely new policy. Another caveat is that our results are based on data from a single selective research university. Consequently, one must be cautious about assuming that the results would apply to other institutions as well. Still, it seems safe to say that university fundraisers' belief that financial aid packages affect future alumni giving are well founded. 


\section{References}

Andreoni, James. "Philanthropy.” in Kolm, Serge-Christophe and Jean Mercier Ythier, Handbook of the Economics of Giving, Altruism, and Reciprocity. Vol. 2, Elsevier, 2006, pp. 1202-1269.

Andreoni, James and Lisa Vesterlund. "Which is the Fairer Sex? Gender Differences in Altruism.” Quarterly Journal of Economics. Vol. 116, No. 1, p. 293. Feb 2001.

Baade, Robert A. and Jeffrey O. Sundberg, What Determines Alumni Generosity?” Economics of Education Review, volume 15, no. 1, 1996, pp. 75-81.

Behrman, Jehr R. and Paul Taubman, “The Intergenerational Correlation between Children's Adult Earnings and Their Parents' Income: Results from the Michigan Panel Survey of Income Dynamics," Review of Income and Wealth 36, No. 2, June 1990, pp. 115-127.

Bristol, Ralph, “How Much Will Alumni Give in the Future?” Planning for Higher Education 20, Winter 1991-92, pp. 1-12.

Bombardieri, Marcella. "Colleges Fear Debt Puts Damper on Donations.” The Boston Globe. July 9, 2007.

Clotfelter, Charles, "Who Are the Alumni Donors? Giving by Two Generations of Alumni from Selective Colleges,” Nonprofit Management and Leadership 12, Winter 2001, pp. 119138.

Clotfelter, Charles, “Alumni Giving to Elite Private Colleges and Universities,” Economics of Education Review 22, 2003, pp. 109-120.

College Board, Advocacy and Policy Center, Trends in Student Aid 2010, http://trends.collegeboard.org/downloads/Student_Aid_2010.pdf

Cochi-Ficano, Carlena and Brendan Cunningham, "The Determinants of Donative Revenue Flows from Alumni of Higher Education: An Empirical Inquiry," Journal of Human Resources 37, no. 3, Summer 2002, pp. 540-569.

Council for Aid to Education. "Colleges and Universities Raise \$28 Billion in 2010.” February 2, 2011. http://www.cae.org/content/pdf/VSE_2010_Press_Release.pdf.

Dynarksi, Susan, "Hope for Whom? Financial Aid for the Middle Class and Its Impact on College Attendance,” National Bureau of Economic Research, Working Paper No. 7756, June 2000.

Ehrenberg, Ronald and Christopher L. Smith, "The Sources and Uses of Annual Giving at Private Research Universities,” Economics of Education Review 22, June 2003, pp. 223-341. 
Falk, Armin, “Gift Exchange in the Field,” Econometrica 75, 2007, pp. 1501-1511.

Heckman, James J., “Sample Selection Bias as a Specification Error,” Econometrica 47, 1979, pp. 153-161.

Holmes, Jessica, "Prestige, Charitable Deductions and Other Determinants of Alumni Giving: Evidence from a Highly Selective Liberal Arts College,” Economics of Education Review 28, 2009, pp. 18-28.

Huck, Steffen and Imram Rasul. "Comparing Charitable Fundraising Schemes: Evidence from a Natural Field Experiment.” Manuscript, October 2007.

Lara, Christen and Daniel K.N. Johnson, “The Anatomy of a Likely Donor: Econometric Evidence on Philanthropy to Higher Education,” Working Paper 2008-05, Colorado College, July 2008.

Leung, Siu Fai and Shihti Yu, “On the Choice between Sample Selection and Two-Part Models,” Journal of Econometrics 72, 1996, pp. 197-229.

Marr, Kelly A., Charles H. Mullin and John J. Siegfried, "Undergraduate Financial Aid and Subsequent Alumni Giving Behavior,” The Quarterly Review of Economics and Finance 45, 2005, pp. 123-143.

McDearmon, J. Travis and Kathryn Shirley, "Characteristics and Institutional Factors Related to Young Alumni Donors and Non-Donors,” International Journal of Educational Advancement, volume 9, 2009, pp. 83-95.

Monks, James, "Patterns of Giving to One’s Alma Mater among Young Graduates from Selective Institutions,” Economics of Education Review 22, 2003, pp. 121-130.

Meer, Jonathan and Harvey S. Rosen, “The Impact of Athletic Performance on Alumni Giving: An Analysis of Micro Data,” Economics of Education Review, June 2009, pp. 287-294.

Shulman, James L. and William G. Bowen, The Game of Life, Princeton University Press: Princeton, 2001. 


\section{Appendix}

Appendix Table A1 presents the summary statistics for the variables used in our econometric model. The remaining tables show the results when we augment our basic models with interactions of the financial aid variables with indicators for race, gender, and age, respectively.

Table A2 shows the outcomes when we interact the financial aid variables with the indicators for race. ${ }^{19}$ Consider the first panel, which shows the results for loans. We do not report the regression coefficients themselves. Rather, for each racial category, we show the sum of the main effect of a given loan variable and the coefficient on the interaction between the loan variable and the race dichotomous variable. In short, the figures show the total effects of each loan variable for the respective ethnic categories. The coefficient for an ethnic group is italicized if it is statistically different at the 5 percent level from the corresponding figure for whites. The bottom portion of the first panel shows the p-value of a test of the hypothesis that the interaction terms are jointly significant (for example, 0.110 for the probability of making a gift) and the pvalue of a test of the hypothesis that the average marginal effects for each ethnic group are equal ( 0.001). The figures suggest, then, that the interactions do not jointly improve the explanatory power of the equation, but one can reject the hypothesis that the average marginal effects of loans are the same across ethnic groups. It is important to note that the figures in the table measure the total impact of each financial aid variable on giving, including the estimate of the associated intercept. However, the average marginal effects recorded toward the bottom of the panel do not include the effect of the intercept, because they measure the impact of an incremental increase of a given type of aid rather than the leap from no aid to some aid. The next two panels report the same information for scholarships and campus jobs.

Table A3 reports the results for interactions by gender, and Table A4 does the same for interactions with age. The indicator for age takes a value of one if, in a given year, the individual graduated 10 or more years ago, and zero otherwise, and is estimated for the sample of those who were out of college for at least 10 years. Coefficients for men and older alumni that are significantly different from the corresponding coefficients for women and younger alumni, respectively, are italicized. As noted in the text, there are generally (but not always) no statistically discernible differences by demographic group.

\footnotetext{
${ }^{19}$ Because there are so few Native Americans in our sample, they are not included in this analysis.
} 


\section{Table 1* \\ Probability of Making a Gift}

\begin{tabular}{|c|c|c|c|}
\hline & $\begin{array}{c}\text { (1) } \\
\text { Main } \\
\text { Specification }\end{array}$ & $\begin{array}{c}\text { (2) } \\
\text { Including Field } \\
\text { Variables }\end{array}$ & $\begin{array}{l}\text { (3) } \\
\text { Including 3-Digit } \\
\text { ZIP Effects }\end{array}$ \\
\hline Loans & $\begin{array}{c}0.00407^{* *} \\
(0.00168)\end{array}$ & $\begin{array}{c}0.00493^{* *} \\
(0.00210)\end{array}$ & $\begin{array}{c}0.00457^{* *} \\
(0.00164)\end{array}$ \\
\hline Loans $^{2}$ & $\begin{array}{c}-0.000155^{* *} \\
\left(4.35 \times 10^{-5}\right)\end{array}$ & $\begin{array}{l}-0.000184^{* *} \\
\left(4.35 \times 10^{-5}\right)\end{array}$ & $\begin{array}{l}-0.000167^{* *} \\
\left(4.21 \times 10^{-5}\right)\end{array}$ \\
\hline Any Loan Aid & $\begin{array}{c}-0.0357 * * \\
(0.0175)\end{array}$ & $\begin{array}{c}-0.0436 * * \\
(0.0201)\end{array}$ & $\begin{array}{c}-0.0390 * * \\
(0.0172)\end{array}$ \\
\hline $\begin{array}{l}\text { p-Value of Joint Significance } \\
\text { of Loan Variables }\end{array}$ & 0.000 & 0.001 & 0.000 \\
\hline Scholarships & $\begin{array}{c}0.000551 \\
(0.000388)\end{array}$ & $\begin{array}{c}0.000177 \\
(0.000423)\end{array}$ & $\begin{array}{c}0.000515 \\
(0.000383)\end{array}$ \\
\hline Scholarships ${ }^{2}$ & $\begin{array}{l}-3.23 \times 10^{-6} \\
\left(2.42 \times 10^{-6}\right)\end{array}$ & $\begin{array}{l}-1.21 \times 10^{-6} \\
\left(2.69 \times 10^{-6}\right)\end{array}$ & $\begin{array}{l}-3.18 \times 10^{-6} \\
\left(2.38 \times 10^{-6}\right)\end{array}$ \\
\hline Any Scholarship Aid & $\begin{array}{l}-0.00704 \\
(0.0181)\end{array}$ & $\begin{array}{l}0.00260 \\
(0.0191)\end{array}$ & $\begin{array}{l}-0.0123 \\
(0.0180)\end{array}$ \\
\hline $\begin{array}{l}\text { p-Value of Joint Significance } \\
\text { of Scholarship Variables }\end{array}$ & 0.528 & 0.950 & 0.609 \\
\hline Jobs & $\begin{array}{l}-0.00581^{* *} \\
(0.00244)\end{array}$ & $\begin{array}{l}-0.00460 * \\
(0.00254)\end{array}$ & $\begin{array}{c}-0.00540 * * \\
(0.00241)\end{array}$ \\
\hline Jobs $^{2}$ & $\begin{array}{l}0.000386^{* *} \\
\left(8.85 \times 10^{-5}\right)\end{array}$ & $\begin{array}{l}0.000335^{* *} \\
\left(8.82 \times 10^{-5}\right)\end{array}$ & $\begin{array}{l}0.000383 * * \\
\left(8.73 \times 10^{-5}\right)\end{array}$ \\
\hline Any Job Aid & $\begin{array}{c}-0.00907 \\
(0.0191)\end{array}$ & $\begin{array}{c}-0.0107 \\
(0.0200)\end{array}$ & $\begin{array}{c}-0.00282 \\
(0.0189)\end{array}$ \\
\hline $\begin{array}{l}\text { p-Value of Joint Significance } \\
\text { of Job Variables }\end{array}$ & 0.000 & 0.000 & 0.000 \\
\hline $\mathrm{N}$ & 137,699 & 114,108 & 137,699 \\
\hline
\end{tabular}

*Each column shows the incremental effect of the respective variables on the probability of making a gift in a given year, based on a linear probability model. Column (2) includes indicator variables for the field in which the individual works, and Column (3) includes indicator variables for the individual's ZIP code. Each regression includes on the right hand side the variables listed in Table A1 as well as class effects, location effects and, time effects. Standard errors are in parentheses. Coefficients significant at the 5 percent level are marked with $* *$, while those significant at the 10 percent level are marked with *. 
Table 2*

\section{Log Amount Conditional on Giving}

\begin{tabular}{|c|c|c|c|}
\hline & $\begin{array}{c}(1) \\
\text { Main } \\
\text { Specification }\end{array}$ & $\begin{array}{c}(2) \\
\text { Including Field } \\
\text { Variables }\end{array}$ & $\begin{array}{c}\text { (3) } \\
\text { Including 3-Digit } \\
\text { ZIP Effects }\end{array}$ \\
\hline Loans & $\begin{array}{l}-0.00344 \\
(0.00520)\end{array}$ & $\begin{array}{l}-0.00575 \\
(0.00609)\end{array}$ & $\begin{array}{l}-0.00294 \\
(0.00505)\end{array}$ \\
\hline Loans $^{2}$ & $\begin{array}{l}2.50 \times 10^{-5} \\
(0.000145)\end{array}$ & $\begin{array}{l}8.43 \times 10^{-5} \\
(0.000171)\end{array}$ & $\begin{array}{c}1.27 \times 10^{-5} \\
(0.000139)\end{array}$ \\
\hline Any Loan Aid & $\begin{array}{l}-0.0679 \\
(0.0512)\end{array}$ & $\begin{array}{l}-0.0475 \\
(0.0568)\end{array}$ & $\begin{array}{l}-0.0742 \\
(0.0502)\end{array}$ \\
\hline $\begin{array}{l}\text { p-Value of Joint Significance } \\
\text { of Loan Variables }\end{array}$ & 0.002 & 0.004 & 0.001 \\
\hline Scholarships & $\begin{array}{c}0.00162 \\
(0.00108)\end{array}$ & $\begin{array}{c}0.00180 \\
(0.00117)\end{array}$ & $\begin{array}{l}0.00179 * \\
(0.00107)\end{array}$ \\
\hline Scholarships $^{2}$ & $\begin{array}{l}-4.90 \times 10^{-6} \\
\left(6.92 \times 10^{-6}\right)\end{array}$ & $\begin{array}{l}-6.46 \times 10^{-6} \\
\left(7.69 \times 10^{-6}\right)\end{array}$ & $\begin{array}{l}-5.44 \times 10^{-6} \\
\left(6.82 \times 10^{-6}\right)\end{array}$ \\
\hline Any Scholarship Aid & $\begin{array}{l}-0.188^{* *} \\
(0.0492)\end{array}$ & $\begin{array}{l}-0.184^{* *} \\
(0.0512)\end{array}$ & $\begin{array}{l}-0.186^{* *} \\
(0.0483)\end{array}$ \\
\hline $\begin{array}{l}\text { p-Value of Joint Significance } \\
\text { of Scholarship Variables }\end{array}$ & 0.000 & 0.001 & 0.000 \\
\hline Jobs & $\begin{array}{l}-0.000383 \\
(0.00651)\end{array}$ & $\begin{array}{l}-0.00231 \\
(0.00681)\end{array}$ & $\begin{array}{l}-0.00123 \\
(0.00641)\end{array}$ \\
\hline Jobs $^{2}$ & $\begin{array}{l}-0.000147 \\
(0.000216)\end{array}$ & $\begin{array}{l}-8.51 \times 10^{-5} \\
(0.000226)\end{array}$ & $\begin{array}{l}-7.69 \times 10^{-5} \\
(0.000216)\end{array}$ \\
\hline Any Job Aid & $\begin{array}{c}0.0149 \\
(0.0522)\end{array}$ & $\begin{array}{c}0.0451 \\
(0.0541)\end{array}$ & $\begin{array}{c}0.0196 \\
(0.0514)\end{array}$ \\
\hline $\begin{array}{l}\text { p-Value of Joint Significance } \\
\text { of Job Variables }\end{array}$ & 0.041 & 0.505 & 0.743 \\
\hline $\mathrm{N}$ & 84,394 & 74,920 & 84,394 \\
\hline
\end{tabular}

*Each column shows the incremental effects of the respective variables on the log amount of the gift, conditional on making a gift, estimated by ordinary least squares and using observations with a positive gift. Column (2) includes indicator variables for the field in which the individual works, and Column (3) includes indicator variables for the individual's ZIP code. Each regression includes on the right hand side the variables listed in Table A1 as well as class effects, location effects and, time effects. Standard errors are in parentheses. Coefficients significant at the 5 percent level are marked with ${ }^{* *}$, while those significant at the 10 percent level are marked with *. 
Table 3*

\section{Probability of Being a Class Leaders}

\begin{tabular}{|c|c|c|c|}
\hline & $\begin{array}{c}(1) \\
\text { Main } \\
\text { Specification }\end{array}$ & $\begin{array}{c}(2) \\
\text { Including Field } \\
\text { Variables }\end{array}$ & $\begin{array}{c}\text { (3) } \\
\text { Including 3-Digit } \\
\text { ZIP Effects }\end{array}$ \\
\hline Loans & $\begin{array}{c}-0.000754 * * \\
(0.000997)\end{array}$ & $\begin{array}{l}-0.00113 \\
(0.00134)\end{array}$ & $\begin{array}{c}-0.000608 * * \\
(0.000971)\end{array}$ \\
\hline Loans $^{2}$ & $\begin{array}{c}2.03 \times 10^{-6} \\
\left(2.77 \times 10^{-5}\right)\end{array}$ & $\begin{array}{c}8.00 \times 10^{-6} \\
\left(3.84 \times 10^{-5}\right)\end{array}$ & $\begin{array}{l}-1.40 \times 10^{-6} \\
\left(2.67 \times 10^{-5}\right)\end{array}$ \\
\hline Any Loan Aid & $\begin{array}{l}-0.00920 \\
(0.00994)\end{array}$ & $\begin{array}{l}-0.00736 \\
(0.0124)\end{array}$ & $\begin{array}{c}-0.0102 \\
(0.00980)\end{array}$ \\
\hline $\begin{array}{l}\text { p-Value of Joint Significance } \\
\text { of Loan Variables }\end{array}$ & 0.005 & 0.005 & 0.005 \\
\hline Scholarships & $\begin{array}{l}0.000369 * \\
(0.000200)\end{array}$ & $\begin{array}{c}0.000345 \\
(0.000235)\end{array}$ & $\begin{array}{l}0.000407 * * \\
(0.000195)\end{array}$ \\
\hline Scholarships $^{2}$ & $\begin{array}{l}-1.45 \times 10^{-6} \\
\left(1.23 \times 10^{-6}\right)\end{array}$ & $\begin{array}{c}-1.38 \times 10^{-6} \\
\left(1.49 \times 10^{-6}\right)\end{array}$ & $\begin{array}{c}-1.61 \times 10^{-6} \\
\left(1.21 \times 10^{-6}\right)\end{array}$ \\
\hline Any Scholarship Aid & $\begin{array}{l}-0.0326 * * \\
(0.00967)\end{array}$ & $\begin{array}{c}-0.0337 * * \\
(0.0111)\end{array}$ & $\begin{array}{l}-0.0325^{* *} \\
(0.00961)\end{array}$ \\
\hline $\begin{array}{l}\text { p-Value of Joint Significance } \\
\text { of Scholarship Variables }\end{array}$ & 0.004 & 0.016 & 0.003 \\
\hline Jobs & $\begin{array}{l}-0.000579 \\
(0.00145)\end{array}$ & $\begin{array}{l}4.76 \times 10^{-5} \\
(0.00158)\end{array}$ & $\begin{array}{l}-0.000765 \\
(0.00143)\end{array}$ \\
\hline Jobs $^{2}$ & $\begin{array}{c}2.38 \times 10^{-5} \\
\left(5.72 \times 10^{-5}\right)\end{array}$ & $\begin{array}{l}-5.94 \times 10^{-7} \\
\left(5.96 \times 10^{-5}\right)\end{array}$ & $\begin{array}{c}3.42 \times 10^{-5} \\
\left(5.71 \times 10^{-5}\right)\end{array}$ \\
\hline Any Job Aid & $\begin{array}{l}-0.00610 \\
(0.0107)\end{array}$ & $\begin{array}{l}-0.00313 \\
(0.0123)\end{array}$ & $\begin{array}{l}-0.00415 \\
(0.0107)\end{array}$ \\
\hline $\begin{array}{l}\text { p-Value of Joint Significance } \\
\text { of Job Variables }\end{array}$ & 0.708 & 0.992 & 0.745 \\
\hline $\mathrm{N}$ & 137,699 & 114,108 & 137,699 \\
\hline
\end{tabular}

*Each column shows the incremental effects of the respective financial aid variables on being a "class leader" in a given year, where a class leader is defined as an individual who donated an amount greater than or equal to the $90^{\text {th }}$ percentile of gifts in his or her class. Estimation is based on a linear probability model. Column (2) includes indicator variables for the field in which the individual works, and Column (3) includes indicator variables for the individual's ZIP code. Each regression includes on the right hand side the variables listed in Table A1 as well as class effects, location effects and, time effects. Standard errors are in parentheses. Coefficients significant at the 5 percent level are marked with ${ }^{* *}$, while those significant at the 10 percent level are marked with *. 


\section{Table A1* \\ Variable Definitions and Summary Statistics}

\begin{tabular}{|c|c|c|c|}
\hline Variable & Description & Mean & $\begin{array}{l}\text { Standard } \\
\text { Deviation }\end{array}$ \\
\hline TotalYear & Total giving for year (2009 dollars) conditional on making a gift & 173.26 & 2753.20 \\
\hline Didgive & 1 if any donation given in year & 0.613 & 0.487 \\
\hline Loans & Total loan aid (2009 dollars) conditional on receiving loan aid & 7252 & 9735 \\
\hline Any Loan Aid & Received any loan aid & 0.444 & 0.497 \\
\hline Scholarships & $\begin{array}{c}\text { Total scholarship aid (2009 dollars) conditional on receiving scho- } \\
\text { larship aid }\end{array}$ & 29,327 & 43,691 \\
\hline Any Scholarship Aid & Received any scholarship aid & 0.442 & 0.497 \\
\hline Campus Jobs & Total job aid (2009 dollars) conditional on receiving job aid & 3940 & 5564 \\
\hline Any Job Aid & Received any job aid & 0.404 & 0.491 \\
\hline Yearssince & Number of years since graduation & 6.18 & 3.83 \\
\hline Yearssince2 & Number of years since graduation, squared & 52.87 & 57.21 \\
\hline Spouseisalum & 1 if the spouse is an alumnus & 0.151 & 0.358 \\
\hline Male & 1 if the alumnus is male & 0.543 & 0.498 \\
\hline \multicolumn{4}{|l|}{ Race/Ethnicity } \\
\hline White & Omitted Category: 1 if the alumnus is White & 0.743 & 0.437 \\
\hline Amerind & 1 if the alumnus is a Native American & 0.0045 & 0.0671 \\
\hline Black & 1 if the alumnus is Black & 0.0666 & 0.249 \\
\hline Hispanic & 1 if the alumnus is Hispanic & 0.0582 & 0.234 \\
\hline Asian & 1 if the alumnus is Asian & 0.127 & 0.333 \\
\hline \multicolumn{4}{|l|}{ Secondary Schooling } \\
\hline Public & Omitted Category: 1 if the alumnus attended public school & 0.557 & 0.497 \\
\hline Boarding & 1 if the alumnus attended boarding school & 0.128 & 0.334 \\
\hline Private & 1 if the alumnus attended private school & 0.314 & 0.464 \\
\hline School - Other & 1 if the alumnus attended another type of school & 0.0017 & 0.0415 \\
\hline SATmath & $\begin{array}{l}\text { SAT math score. Scores prior to } 1996 \text { are adjusted to reflect re- } \\
\text { centering of the scoring scale. }\end{array}$ & 714 & 67.4 \\
\hline
\end{tabular}


SATverbal

SAT verbal score. Scores prior to 1996 are adjusted to reflect recentering of the scoring scale.

\begin{tabular}{|c|c|c|c|}
\hline \multicolumn{4}{|l|}{$\begin{array}{c}\text { Admissions Office } \\
\text { "Non-Academic" } \\
\text { Ranking }\end{array}$} \\
\hline A & $\begin{array}{l}\text { Omitted Category: } 1 \text { if the alumnus received the highest non- } \\
\text { academic ranking from the admissions office }\end{array}$ & 0.0224 & 0.148 \\
\hline B & $\begin{array}{l}1 \text { if the alumnus received the second highest non-academic ranking } \\
\text { from the admissions office }\end{array}$ & 0.193 & 0.395 \\
\hline $\mathrm{C}$ & $\begin{array}{l}1 \text { if the alumnus received the third highest non-academic ranking } \\
\text { from the admissions office }\end{array}$ & 0.467 & 0.499 \\
\hline $\mathrm{D}$ & $\begin{array}{l}1 \text { if the alumnus received the fourth highest non-academic ranking } \\
\text { from the admissions office }\end{array}$ & 0.299 & 0.458 \\
\hline $\mathrm{E}$ & $\begin{array}{l}1 \text { if the alumnus received the fifth highest non-academic ranking } \\
\text { from the admissions office }\end{array}$ & 0.0192 & 0.137 \\
\hline \multicolumn{4}{|l|}{$\begin{array}{l}\text { Admissions Office } \\
\text { "Academic" Ranking }\end{array}$} \\
\hline A & $\begin{array}{c}\text { Omitted Category: } 1 \text { if the alumnus received the highest academic } \\
\text { ranking from the admissions office }\end{array}$ & 0.228 & 0.419 \\
\hline B & $\begin{array}{l}1 \text { if the alumnus received the second highest academic ranking } \\
\text { from the admissions office }\end{array}$ & 0.407 & 0.491 \\
\hline $\mathrm{C}$ & $\begin{array}{l}1 \text { if the alumnus received the third highest academic ranking from } \\
\text { the admissions office }\end{array}$ & 0.217 & 0.412 \\
\hline $\mathrm{D}$ & $\begin{array}{l}1 \text { if the alumnus received the fourth highest academic ranking from } \\
\text { the admissions office }\end{array}$ & 0.121 & 0.326 \\
\hline $\mathrm{E}$ & $\begin{array}{l}1 \text { if the alumnus received the fifth highest academic ranking from } \\
\text { the admissions office }\end{array}$ & 0.0268 & 0.161 \\
\hline Clubsport & 1 if the alumnus played on a club team & 0.130 & 0.337 \\
\hline Honors & 1 if the alumnus graduated magna, summa, or cum laude & 0.463 & 0.499 \\
\hline Greek & 1 if the alumnus was a member of a fraternity or sorority & 0.730 & 0.444 \\
\hline Athlete & 1 if the alumnus played a varsity sport & 0.377 & 0.485 \\
\hline \multicolumn{4}{|l|}{ Major } \\
\hline Molbio & Omitted Category: 1 if the alumnus majored in molecular biology & 0.0591 & 0.236 \\
\hline Small Social Science & $\begin{array}{l}1 \text { if the alumnus majored in Anthropology, Urban Studies, or } \\
\text { Sociology. }\end{array}$ & 0.0375 & 0.190 \\
\hline English & 1 if the alumnus majored in English & 0.101 & 0.301 \\
\hline Economics & 1 if the alumnus majored in Economics & 0.0889 & 0.285 \\
\hline Public Policy & 1 if the alumnus majored in Public Policy & 0.0634 & 0.244 \\
\hline
\end{tabular}


Political Science

Psychology

History

MAE

$\mathrm{EE} / \mathrm{CS}$

Arch \& Civ

Small Humanities

Small Engineering

Small Sciences
1 if the alumnus majored in Political Science

1 if the alumnus majored in Psychology

1 if the alumnus majored in History

1 if the alumnus majored in Mechanical/Aerospace Engineering

1 if the alumnus majored in Electrical Engineering or Computer Science

1 if the alumnus majored in Architecture or Civil Engineering

1 if the alumnus majored in Art, Art History, Classics, East Asian Studies, Linguistics, Music, Near Eastern Studies, Philosophy, Religion, or Languages and Literature departments

1 if the alumnus majored in "Engineering”, Operations Research and Financial Engineering, or Chemical Engineering

1 if the alumnus majored in Applied Mathematics, Astrophysics, Biochemistry, Biology, Chemistry, Ecology and Evolutionary Biology, Geology, Mathematics, Physics, or Statistics
0.0998

0.300

0.0470

0.212

0.110

0.313

0.0348

0.183

0.0589

0.235

0.0565

0.109

0.312

0.0321

0.176

0.102

0.302

\section{Minor}

No Minor

Omitted Category: 1 if the alumnus received no minor

0.682

0.466

African/African-

American Studies

American Studies

Latin

Finance

Theater

Public Policy

Other Engineering

Other Sciences

Other Humanities

Teaching

Reunion

1 if the year after graduation is a multiple of 5

1 if the alumnus received a minor in African or African-American Studies

1 if the alumnus received a minor in American Studies

1 if the alumnus received a minor in Latin

1 if the alumnus received a minor in Finance

1 if the alumnus received a minor in Theater

1 if the alumnus received a minor in Public Policy

1 if the alumnus received a minor in Architecture, Basic Engineering, Bioengineering, Electrical Engineering, Geological Engineering, Management, Materials Sciences, or Robotics.

1 if the alumnus received a minor in Applied and Computational Mathematics, Biophysics, Cognitive Studies, Environmental Studies, Science in Human Affairs, or Neuroscience.

1 if the alumnus received a minor in a humanities field

1 if the alumnus received a teaching certificate
0.295

0.0172

0.130

$0.0221 \quad 0.147$

$0.03004 \quad 0.171$

$0.0078 \quad 0.0880$

$0.0231 \quad 0.150$

$0.0184 \quad 0.134$

$0.0199 \quad 0.140$

$0.0559 \quad 0.230$

$0.162 \quad 0.368$

$0.0562 \quad 0.230$ 


\section{Post Baccalaureate \\ Education}

\begin{tabular}{cccc}
$\begin{array}{c}\text { No Advanced } \\
\text { PhD }\end{array}$ & Omitted Category: 1 if the alumnus has no advanced degree & 0.794 & 0.404 \\
Masters & 1 if the alumnus has a Ph.D. or equivalent degree & 0.0387 & 0.183 \\
JD & 1 if the alumnus has a masters & 0.0619 & 0.241 \\
MD/DDS & 1 if the alumnus has a JD & 0.0428 & 0.202 \\
MBA & 1 if the alumnus has a medical degree & 0.0411 & 0.198 \\
\hline
\end{tabular}

* These summary statistics are based on 137,699 observations between 1994 and 2009 of 13,831 alumni who graduated from 1993 to 2005. The unit of observation is the alumnus-year giving opportunity. 
Table A2*

Race and the Effects of Financial Aid

\begin{tabular}{|c|c|c|c|c|}
\hline & & $\begin{array}{c}\text { (1) } \\
\text { Probability } \\
\text { of Making a Gift }\end{array}$ & $\begin{array}{c}(2) \\
\text { Log Amount } \\
\text { Conditional on Giving }\end{array}$ & $\begin{array}{c}(3) \\
\text { Probability of Being a } \\
\text { Class Leader }\end{array}$ \\
\hline \multicolumn{5}{|c|}{ Loans } \\
\hline \multirow{3}{*}{ White } & Linear & $\begin{array}{l}0.00514^{* *} \\
(0.00199)\end{array}$ & $\begin{array}{l}-0.00840 \\
(0.00630)\end{array}$ & $\begin{array}{l}-0.00151 \\
(0.00127)\end{array}$ \\
\hline & Quadratic & $\begin{array}{c}-0.000179 * * \\
\left(5.15 \times 10^{-5}\right)\end{array}$ & $\begin{array}{c}0.000197 \\
(0.000171)\end{array}$ & $\begin{array}{r}2.27 \times 10^{-5} \\
\left(3.55 \times 10^{-5}\right)\end{array}$ \\
\hline & Indicator & $\begin{array}{c}-0.0465^{* *} \\
(0.0212)\end{array}$ & $\begin{array}{l}-0.0369 \\
(0.0641)\end{array}$ & $\begin{array}{l}-0.00501 \\
(0.0128)\end{array}$ \\
\hline \multirow{3}{*}{ Black } & Linear & $\begin{array}{l}-0.0109 * \\
(0.00579)\end{array}$ & $\begin{array}{l}0.00648 \\
(0.0149)\end{array}$ & $\begin{array}{l}-0.00245 \\
(0.00243)\end{array}$ \\
\hline & Quadratic & $\begin{array}{c}0.000122 \\
(0.000138)\end{array}$ & $\begin{array}{l}-0.000254 \\
(0.000376)\end{array}$ & $\begin{array}{c}2.98 \times 10^{-5} \\
\left(5.58 \times 10^{-5}\right)\end{array}$ \\
\hline & Indicator & $\begin{array}{c}0.0692 \\
(0.0634)\end{array}$ & $\begin{array}{l}-0.202 \\
(0.145)\end{array}$ & $\begin{array}{l}0.00868 \\
(0.0266)\end{array}$ \\
\hline \multirow{3}{*}{ Hispanic } & Linear & $\begin{array}{c}0.00910 \\
(0.00597)\end{array}$ & $\begin{array}{l}-0.0123 \\
(0.0154)\end{array}$ & $\begin{array}{c}0.00131 \\
(0.00303)\end{array}$ \\
\hline & Quadratic & $\begin{array}{l}-0.000209 \\
(0.000156)\end{array}$ & $\begin{array}{c}9.92 \times 10^{-5} \\
(0.000430)\end{array}$ & $\begin{array}{l}-3.27 \times 10^{-5} \\
\left(9.10 \times 10^{-5}\right)\end{array}$ \\
\hline & Indicator & $\begin{array}{l}-0.0793 \\
(0.0654)\end{array}$ & $\begin{array}{c}0.243 \\
(0.156)\end{array}$ & $\begin{array}{c}0.0219 \\
(0.0331)\end{array}$ \\
\hline \multirow{3}{*}{ Asian } & Linear & $\begin{array}{c}0.00331 \\
(0.00549)\end{array}$ & $\begin{array}{c}0.0168 \\
(0.0189)\end{array}$ & $\begin{array}{c}0.00402 \\
(0.00312)\end{array}$ \\
\hline & Quadratic & $\begin{array}{l}-8.98 \times 10^{-5} \\
(0.000166)\end{array}$ & $\begin{array}{l}-0.000627 \\
(0.000640)\end{array}$ & $\begin{array}{l}-0.000143 \\
(0.000105)\end{array}$ \\
\hline & Indicator & $\begin{array}{l}-0.0214 \\
(0.0451)\end{array}$ & $\begin{array}{l}-0.210 \\
(0.132)\end{array}$ & $\begin{array}{l}-0.0408^{*} \\
(0.0228)\end{array}$ \\
\hline \multicolumn{2}{|c|}{$\begin{array}{l}\text { p-Value for Joint Significance of } \\
\text { All Interaction Coefficients }\end{array}$} & 0.110 & 0.433 & 0.365 \\
\hline \multicolumn{2}{|c|}{$\begin{array}{l}\text { p-Value for Equality of } \\
\text { Average Marginal Effects }\end{array}$} & 0.001 & 0.431 & 0.181 \\
\hline
\end{tabular}




\begin{tabular}{|c|c|c|c|c|}
\hline \multicolumn{5}{|c|}{ Scholarships } \\
\hline \multirow{3}{*}{ White } & Linear & $\begin{array}{l}0.000958^{*} \\
(0.000503)\end{array}$ & $\begin{array}{l}0.00266^{*} \\
(0.00146)\end{array}$ & $\begin{array}{c}0.000262 \\
(0.000272)\end{array}$ \\
\hline & Quadratic & $\begin{array}{c}-6.99 \times 10^{-6} * * \\
\left(3.31 \times 10^{-6}\right)\end{array}$ & $\begin{array}{l}-1.84 \times 10^{-5 *} \\
\left(9.96 \times 10^{-6}\right)\end{array}$ & $\begin{array}{l}-2.00 \times 10^{-6} \\
\left(1.76 \times 10^{-6}\right)\end{array}$ \\
\hline & Indicator & $\begin{array}{l}-0.00531 \\
(0.0219)\end{array}$ & $\begin{array}{l}-0.227 * * \\
(0.0618)\end{array}$ & $\begin{array}{c}-0.0325^{* *} \\
(0.0127)\end{array}$ \\
\hline \multirow{3}{*}{ Black } & Linear & $\begin{array}{l}0.00232 * \\
(0.00127)\end{array}$ & $\begin{array}{c}0.00176 \\
(0.00305)\end{array}$ & $\begin{array}{c}0.000763 \\
(0.000438)\end{array}$ \\
\hline & Quadratic & $\begin{array}{c}-1.46 \times 10^{-5 * *} \\
\left(7.09 \times 10^{-6}\right)\end{array}$ & $\begin{array}{r}2.43 \times 10^{-6} \\
\left(1.71 \times 10^{-5}\right)\end{array}$ & $\begin{array}{l}-3.96 \times 10^{-6} \\
\left(2.57 \times 10^{-6}\right)\end{array}$ \\
\hline & Indicator & $\begin{array}{l}-0.0524 \\
(0.0711)\end{array}$ & $\begin{array}{l}-0.156 \\
(0.169)\end{array}$ & $\begin{array}{c}-0.000456 \\
(0.0247)\end{array}$ \\
\hline \multirow{3}{*}{ Hispanic } & Linear & $\begin{array}{c}-0.00271^{* *} \\
(0.00129)\end{array}$ & $\begin{array}{c}0.00378 \\
(0.00342)\end{array}$ & $\begin{array}{c}0.000508 \\
(0.000614)\end{array}$ \\
\hline & Quadratic & $\begin{array}{l}1.61 \times 10^{-5} * * \\
\left(7.37 \times 10^{-6}\right)\end{array}$ & $\begin{array}{l}-1.97 \times 10^{-5} \\
\left(1.97 \times 10^{-5}\right)\end{array}$ & $\begin{array}{l}-1.08 \times 10^{-6} \\
\left(3.36 \times 10^{-6}\right)\end{array}$ \\
\hline & Indicator & $\begin{array}{c}0.0998 \\
(0.0672)\end{array}$ & $\begin{array}{c}-0.204 \\
(0.165)\end{array}$ & $\begin{array}{c}-0.0806^{* *} \\
(0.0316)\end{array}$ \\
\hline \multirow{3}{*}{ Asian } & Linear & $\begin{array}{l}0.000287 \\
(0.00100)\end{array}$ & $\begin{array}{c}0.00116 \\
(0.00262)\end{array}$ & $\begin{array}{c}0.000844 \\
(0.000462)\end{array}$ \\
\hline & Quadratic & $\begin{array}{l}-3.76 \times 10^{-7} \\
\left(6.13 \times 10^{-6}\right)\end{array}$ & $\begin{array}{c}8.85 \times 10^{-6} \\
\left(1.61 \times 10^{-5}\right)\end{array}$ & $\begin{array}{l}-2.51 \times 10^{-6} \\
\left(2.96 \times 10^{-6}\right)\end{array}$ \\
\hline & Indicator & $\begin{array}{l}-0.0158 \\
(0.0433)\end{array}$ & $\begin{array}{r}-0.00777 \\
(0.0955)\end{array}$ & $\begin{array}{l}-0.0194 \\
(0.0158)\end{array}$ \\
\hline \multicolumn{2}{|c|}{$\begin{array}{l}\text { p-Value for Joint Significance of } \\
\text { All Interaction Coefficients }\end{array}$} & 0.162 & 0.005 & 0.010 \\
\hline \multicolumn{2}{|c|}{$\begin{array}{l}\text { p-Value for Equality of } \\
\text { Average Marginal Effects }\end{array}$} & 0.143 & 0.987 & 0.423 \\
\hline
\end{tabular}




\begin{tabular}{|c|c|c|c|c|}
\hline \multicolumn{5}{|c|}{ Campus Jobs } \\
\hline \multirow{3}{*}{ White } & Linear & $\begin{array}{c}-0.00738 * * \\
(0.00288)\end{array}$ & $\begin{array}{l}-0.000784 \\
(0.00784)\end{array}$ & $\begin{array}{l}-0.000411 \\
(0.00184)\end{array}$ \\
\hline & Quadratic & $\begin{array}{c}0.000447 * * \\
(0.000100)\end{array}$ & $\begin{array}{l}-0.000133 \\
(0.000251)\end{array}$ & $\begin{array}{c}0.0000278 \\
(0.0000734)\end{array}$ \\
\hline & Indicator & $\begin{array}{l}-0.0219 \\
(0.0228)\end{array}$ & $\begin{array}{c}0.0186 \\
(0.0643)\end{array}$ & $\begin{array}{l}-0.00953 \\
(0.0140)\end{array}$ \\
\hline \multirow{3}{*}{ Black } & Linear & $\begin{array}{l}-0.00154 \\
(0.00707)\end{array}$ & $\begin{array}{c}0.0102 \\
(0.0166)\end{array}$ & $\begin{array}{l}-0.000141 \\
(0.00276)\end{array}$ \\
\hline & Quadratic & $\begin{array}{c}0.000262 \\
(0.000243)\end{array}$ & $\begin{array}{l}-0.000374 \\
(0.000558)\end{array}$ & $\begin{array}{l}3.21 \times 10^{-5} \\
(0.000107)\end{array}$ \\
\hline & Indicator & $\begin{array}{l}0.0593 \\
(0.0657)\end{array}$ & $\begin{array}{l}-0.0471 \\
(0.149)\end{array}$ & $\begin{array}{r}-0.00445 \\
(0.0235)\end{array}$ \\
\hline \multirow{3}{*}{ Hispanic } & Linear & $\begin{array}{l}-0.00255 \\
(0.0122)\end{array}$ & $\begin{array}{l}-0.0312 \\
(0.0226)\end{array}$ & $\begin{array}{l}-0.00110 \\
(0.00522)\end{array}$ \\
\hline & Quadratic & $\begin{array}{c}0.000273 \\
(0.000501)\end{array}$ & $\begin{array}{c}0.000786 \\
(0.000752)\end{array}$ & $\begin{array}{l}-1.89 \times 10^{-5} \\
(0.000183)\end{array}$ \\
\hline & Indicator & $\begin{array}{l}-0.00839 \\
(0.0794)\end{array}$ & $\begin{array}{l}0.0731 \\
(0.182)\end{array}$ & $\begin{array}{l}-0.00834 \\
(0.0370)\end{array}$ \\
\hline \multirow{3}{*}{ Asian } & Linear & $\begin{array}{l}-0.00152 \\
(0.00823)\end{array}$ & $\begin{array}{l}-0.00351 \\
(0.0270)\end{array}$ & $\begin{array}{l}-0.00219 \\
(0.00515)\end{array}$ \\
\hline & Quadratic & $\begin{array}{c}3.73 \times 10^{-5} \\
(0.000363)\end{array}$ & $\begin{array}{c}-8.00 \times 10^{-5} \\
(0.00132)\end{array}$ & $\begin{array}{c}6.58 \times 10^{-5} \\
(0.000281)\end{array}$ \\
\hline & Indicator & $\begin{array}{c}0.0213 \\
(0.0527)\end{array}$ & $\begin{array}{c}0.00443 \\
(0.139)\end{array}$ & $\begin{array}{c}0.0112 \\
(0.0241)\end{array}$ \\
\hline \multicolumn{2}{|c|}{$\begin{array}{l}\text { p-Value for Joint Significance of } \\
\text { All Interaction Coefficients }\end{array}$} & 0.430 & 0.972 & 0.979 \\
\hline \multicolumn{2}{|c|}{$\begin{array}{l}\text { p-Value for Equality of } \\
\text { Average Marginal Effects }\end{array}$} & 0.421 & 0.520 & 0.906 \\
\hline
\end{tabular}

*This table shows, for each racial category, the sum of the main effect of a given financial aid variable and the coefficient on the interaction between the financial aid variable and the race dichotomous variable. Coefficients for each race that are significantly different from the corresponding coefficient for whites are italicized. Coefficients significant at the 5 percent level are marked with **, while those significant at the 10 percent level are marked with *. 
Table A3*

Gender and the Effects of Financial Aid

\begin{tabular}{|c|c|c|c|c|}
\hline & & $\begin{array}{c}\text { (1) } \\
\text { Probability } \\
\text { of Making a Gift }\end{array}$ & $\begin{array}{c}\text { (2) } \\
\text { Log Amount } \\
\text { Conditional on Giving }\end{array}$ & $\begin{array}{l}\text { (3) } \\
\text { Probability of Being a } \\
\text { Class Leader }\end{array}$ \\
\hline \multicolumn{5}{|c|}{ Loans } \\
\hline \multirow{3}{*}{ Female } & Linear & $\begin{array}{c}0.00211 \\
(0.00264)\end{array}$ & $\begin{array}{l}-0.00623 \\
(0.00777)\end{array}$ & $\begin{array}{l}-0.000624 \\
(0.00151)\end{array}$ \\
\hline & Quadratic & $\begin{array}{c}-0.000117 \\
\left(7.14 \times 10^{-5}\right)\end{array}$ & $\begin{array}{c}0.000107 \\
(0.000219)\end{array}$ & $\begin{array}{c}7.41 \times 10^{-6} \\
\left(4.44 \times 10^{-5}\right)\end{array}$ \\
\hline & Indicator & $\begin{array}{c}-0.0277 * * \\
(0.0260)\end{array}$ & $\begin{array}{c}0.0209 \\
(0.0692)\end{array}$ & $\begin{array}{l}-3.15 \times 10^{-5} \\
(0.0136)\end{array}$ \\
\hline \multirow{3}{*}{ Male } & Linear & $\begin{array}{c}0.00552 * * \\
(0.00217)\end{array}$ & $\begin{array}{l}-0.000542 \\
(0.00691)\end{array}$ & $\begin{array}{l}-0.000849 \\
(0.00131)\end{array}$ \\
\hline & Quadratic & $\begin{array}{c}-0.000180^{* *} \\
\left(5.48 \times 10^{-5}\right)\end{array}$ & $\begin{array}{l}-5.06 \times 10^{-5} \\
(0.0001871)\end{array}$ & $\begin{array}{l}-8.20 \times 10^{-7} \\
\left(3.47 \times 10^{-5}\right)\end{array}$ \\
\hline & Indicator & $\begin{array}{l}-0.0430 * \\
(0.0235)\end{array}$ & $\begin{array}{l}-0.148 * \\
(0.0741)\end{array}$ & $\begin{array}{l}-0.0167 \\
(0.0142)\end{array}$ \\
\hline \multicolumn{2}{|c|}{$\begin{array}{l}\text { p-Value for Joint Significance of } \\
\text { All Interaction Coefficients }\end{array}$} & 0.579 & 0.168 & 0.254 \\
\hline \multicolumn{2}{|c|}{$\begin{array}{l}\text { p-Value for Equality of } \\
\text { Average Marginal Effects }\end{array}$} & 0.284 & 0.602 & 0.786 \\
\hline \multicolumn{5}{|c|}{ Scholarships } \\
\hline \multirow{3}{*}{ Female } & Linear & $\begin{array}{l}0.00156 * * \\
(0.000548)\end{array}$ & $\begin{array}{l}3.20 \times 10^{-5} \\
(0.00137)\end{array}$ & $\begin{array}{c}0.000367 \\
(0.000237)\end{array}$ \\
\hline & Quadratic & $\begin{array}{c}-8.59 \times 10^{-6 * * *} \\
\left(3.42 \times 10^{-6}\right)\end{array}$ & $\begin{array}{c}5.93 \times 10^{-6} \\
\left(8.89 \times 10^{-6}\right)\end{array}$ & $\begin{array}{l}-9.82 \times 10^{-7} \\
\left(1.45 \times 10^{-6}\right)\end{array}$ \\
\hline & Indicator & $\begin{array}{l}-0.0229 \\
(0.0262)\end{array}$ & $\begin{array}{l}-0.228^{* *} \\
(0.0635)\end{array}$ & $\begin{array}{c}-0.0493^{* *} \\
(0.0117)\end{array}$ \\
\hline \multirow{3}{*}{ Male } & Linear & $\begin{array}{l}-0.000413 \\
(0.000544)\end{array}$ & $\begin{array}{c}0.00297 \\
(0.00163)\end{array}$ & $\begin{array}{c}0.000362 \\
(0.000313)\end{array}$ \\
\hline & Quadratic & $\begin{array}{l}1.95 \times 10^{-6} \\
\left(3.38 \times 10^{-6}\right)\end{array}$ & $\begin{array}{l}-1.41 \times 10^{-5} \\
\left(1.03 \times 10^{-5}\right)\end{array}$ & $\begin{array}{l}-1.83 \times 10^{-6} \\
\left(1.94 \times 10^{-6}\right)\end{array}$ \\
\hline & Indicator & $\begin{array}{l}0.00890 \\
(0.0248)\end{array}$ & $\begin{array}{l}-0.150^{* *} \\
(0.0728)\end{array}$ & $\begin{array}{l}-0.0184 \\
(0.0147)\end{array}$ \\
\hline \multicolumn{2}{|c|}{$\begin{array}{l}\text { p-Value for Joint Significance of } \\
\text { All Interaction Coefficients }\end{array}$} & 0.042 & 0.145 & 0.223 \\
\hline \multicolumn{2}{|c|}{$\begin{array}{l}\mathrm{p} \text {-Value for Equality of } \\
\text { Average Marginal Effects }\end{array}$} & 0.007 & 0.200 & 0.837 \\
\hline
\end{tabular}




\begin{tabular}{|c|c|c|c|c|}
\hline \multicolumn{5}{|c|}{ Campus Jobs } \\
\hline \multirow{3}{*}{ Female } & Linear & $\begin{array}{c}-0.00919 * * \\
(0.00343)\end{array}$ & $\begin{array}{l}-0.00735 \\
(0.00794)\end{array}$ & $\begin{array}{l}-0.00169 \\
(0.00172)\end{array}$ \\
\hline & Quadratic & $\begin{array}{l}0.000504 * * \\
(0.000124)\end{array}$ & $\begin{array}{l}-0.000104 \\
(0.000198)\end{array}$ & $\begin{array}{r}3.79 \times 10^{-5} \\
\left(5.68 \times 10^{-5}\right)\end{array}$ \\
\hline & Indicator & $\begin{array}{l}-0.00938 \\
(0.0275)\end{array}$ & $\begin{array}{l}-0.00939 \\
(0.0275)\end{array}$ & $\begin{array}{l}0.00519 \\
(0.0140)\end{array}$ \\
\hline \multirow{3}{*}{ Male } & Linear & $\begin{array}{l}-0.00174 \\
(0.00375)\end{array}$ & $\begin{array}{l}0.00381 \\
(0.0114)\end{array}$ & $\begin{array}{l}0.000251 \\
(0.00242)\end{array}$ \\
\hline & Quadratic & $\begin{array}{c}0.000229 \\
(0.000146)\end{array}$ & $\begin{array}{l}-0.000130 \\
(0.000455)\end{array}$ & $\begin{array}{c}1.27 \times 10^{-5} \\
(0.000105)\end{array}$ \\
\hline & Indicator & $\begin{array}{l}-0.0114 \\
(0.0270)\end{array}$ & $\begin{array}{l}-0.0378 \\
(0.0792)\end{array}$ & $\begin{array}{l}-0.0155 \\
(0.0162)\end{array}$ \\
\hline \multicolumn{2}{|c|}{$\begin{array}{l}\text { p-Value for Joint Significance of } \\
\text { All Interaction Coefficients }\end{array}$} & 0.297 & 0.385 & 0.677 \\
\hline \multicolumn{2}{|c|}{$\begin{array}{l}\text { p-Value for Equality of } \\
\text { Average Marginal Effects }\end{array}$} & 0.159 & 0.309 & 0.414 \\
\hline
\end{tabular}

*This table shows, for each gender, the sum of the main effect of a given financial aid variable and the coefficient on the interaction between the financial aid variable and the gender dichotomous variable. Coefficients for men that are significantly different from the corresponding coefficient for women are italicized. Coefficients significant at the 5 percent level are marked with **, while those significant at the 10 percent level are marked with *. 


\section{Table A4*}

\section{Age and the Effects of Financial Aid}

\begin{tabular}{|c|c|c|c|c|}
\hline & & $\begin{array}{c}(1) \\
\text { Probability } \\
\text { of Making a Gift }\end{array}$ & $\begin{array}{c}(2) \\
\text { Log Amount } \\
\text { Conditional on Giving }\end{array}$ & $\begin{array}{c}(3) \\
\text { Probability of Being a } \\
\text { Class Leader }\end{array}$ \\
\hline \multicolumn{5}{|c|}{ Loans } \\
\hline \multirow{3}{*}{ Younger } & Linear & $\begin{array}{l}0.00456^{*} \\
(0.00234)\end{array}$ & $\begin{array}{l}-0.00545 \\
(0.00694)\end{array}$ & $\begin{array}{l}-0.00205 \\
(0.00150)\end{array}$ \\
\hline & Quadratic & $\begin{array}{l}-0.000155^{* *} \\
\left(5.58 \times 10^{-5}\right)\end{array}$ & $\begin{array}{c}2.69 \times 10^{-5} \\
(0.000178)\end{array}$ & $\begin{array}{r}2.23 \times 10^{-5} \\
\left(4.03 \times 10^{-5}\right)\end{array}$ \\
\hline & Indicator & $\begin{array}{l}-0.0495 * \\
(0.0256)\end{array}$ & $\begin{array}{l}-0.0675 \\
(0.0737)\end{array}$ & $\begin{array}{l}-0.00218 \\
(0.0149)\end{array}$ \\
\hline \multirow{3}{*}{ Older } & Linear & $\begin{array}{c}0.00303 \\
(0.00308)\end{array}$ & $\begin{array}{l}-0.00457 \\
(0.0120)\end{array}$ & $\begin{array}{l}-0.000394 \\
(0.00163)\end{array}$ \\
\hline & Quadratic & $\begin{array}{l}-0.000135^{*} \\
\left(7.52 \times 10^{-5}\right)\end{array}$ & $\begin{array}{c}0.000136 \\
(0.000314)\end{array}$ & $\begin{array}{c}1.28 \times 10^{-6} \\
\left(4.03 \times 10^{-5}\right)\end{array}$ \\
\hline & Indicator & $\begin{array}{l}-0.0137 \\
(0.0336)\end{array}$ & $\begin{array}{l}-0.0318 \\
(0.125)\end{array}$ & $\begin{array}{l}-0.00865 \\
(0.0196)\end{array}$ \\
\hline \multicolumn{2}{|c|}{$\begin{array}{l}\text { p-Value for Joint Significance of } \\
\text { Interaction Coefficients }\end{array}$} & 0.505 & 0.341 & 0.270 \\
\hline \multicolumn{2}{|c|}{$\begin{array}{l}\text { p-Value for Equality of } \\
\text { Average Marginal Effects }\end{array}$} & 0.537 & 0.730 & 0.203 \\
\hline \multicolumn{5}{|c|}{ Scholarships } \\
\hline \multirow{3}{*}{ Younger } & Linear & $\begin{array}{c}0.000562 \\
(0.000584)\end{array}$ & $\begin{array}{c}0.00117 \\
(0.00155)\end{array}$ & $\begin{array}{c}0.000458 \\
(0.000296)\end{array}$ \\
\hline & Quadratic & $\begin{array}{l}-4.15 \times 10^{-6} \\
\left(4.08 \times 10^{-6}\right)\end{array}$ & $\begin{array}{l}-3.21 \times 10^{-6} \\
\left(1.14 \times 10^{-5}\right)\end{array}$ & $\begin{array}{l}-2.38 \times 10^{-6} \\
\left(2.08 \times 10^{-6}\right)\end{array}$ \\
\hline & Indicator & $\begin{array}{l}-0.00577 \\
(0.0237)\end{array}$ & $\begin{array}{l}-0.108^{*} \\
(0.0595)\end{array}$ & $\begin{array}{c}-0.0296 * * \\
(0.0125)\end{array}$ \\
\hline \multirow{3}{*}{ Older } & Linear & $\begin{array}{c}0.000535 \\
(0.000761)\end{array}$ & $\begin{array}{c}0.00130 \\
(0.00285)\end{array}$ & $\begin{array}{c}0.000319 \\
(0.000426)\end{array}$ \\
\hline & Quadratic & $\begin{array}{l}-6.42 \times 10^{-6} \\
\left(5.34 \times 10^{-6}\right)\end{array}$ & $\begin{array}{l}2.13 \times 10^{-6} \\
\left(2.10 \times 10^{-5}\right)\end{array}$ & $\begin{array}{l}-1.08 \times 10^{-6} \\
\left(3.00 \times 10^{-6}\right)\end{array}$ \\
\hline & Indicator & $\begin{array}{c}0.0147 \\
(0.0312)\end{array}$ & $\begin{array}{c}-0.248^{* *} \\
(0.105)\end{array}$ & $\begin{array}{l}-0.0278 \\
(0.0179)\end{array}$ \\
\hline \multicolumn{2}{|c|}{$\begin{array}{l}\text { p-Value for Joint Significance of } \\
\text { Interaction Coefficients }\end{array}$} & 0.210 & 0.254 & 0.947 \\
\hline \multicolumn{2}{|c|}{$\begin{array}{l}\text { p-Value for Equality of } \\
\text { Average Marginal Effects }\end{array}$} & 0.770 & 0.820 & 0.802 \\
\hline
\end{tabular}




\begin{tabular}{|c|c|c|c|c|}
\hline \multicolumn{5}{|c|}{ Campus Jobs } \\
\hline \multirow{3}{*}{ Younger } & Linear & $\begin{array}{l}-0.00326 \\
(0.00325)\end{array}$ & $\begin{array}{l}-5.49 \times 10^{-5} \\
(0.00848)\end{array}$ & $\begin{array}{l}-0.000391 \\
(0.00188)\end{array}$ \\
\hline & Quadratic & $\begin{array}{r}0.000295 * * \\
(0.000107)\end{array}$ & $\begin{array}{l}-1.88 \times 10^{-5} \\
(0.000272)\end{array}$ & $\begin{array}{r}3.79 \times 10^{-5} \\
\left(7.09 \times 10^{-5}\right)\end{array}$ \\
\hline & Indicator & $\begin{array}{l}-0.0211 \\
(0.0250)\end{array}$ & $\begin{array}{l}0.000377 \\
(0.0642)\end{array}$ & $\begin{array}{l}-0.00163 \\
(0.0138)\end{array}$ \\
\hline \multirow{3}{*}{ Older } & Linear & $\begin{array}{l}-0.00689 \\
(0.00422)\end{array}$ & $\begin{array}{l}-0.00685 \\
(0.0137)\end{array}$ & $\begin{array}{l}-0.000715 \\
(0.00244)\end{array}$ \\
\hline & Quadratic & $\begin{array}{c}0.000516^{* *} \\
(0.000139)\end{array}$ & $\begin{array}{l}-0.000231 \\
(0.000361)\end{array}$ & $\begin{array}{l}-1.41 \times 10^{-5} \\
\left(7.65 \times 10^{-5}\right)\end{array}$ \\
\hline & Indicator & $\begin{array}{c}0.0153 \\
(0.0323)\end{array}$ & $\begin{array}{l}0.0619 \\
(0.115)\end{array}$ & $\begin{array}{l}-0.00207 \\
(0.0200)\end{array}$ \\
\hline \multicolumn{2}{|c|}{$\begin{array}{l}\text { p-Value for Joint Significance of } \\
\text { Interaction Coefficients }\end{array}$} & 0.177 & 0.081 & 0.167 \\
\hline \multicolumn{2}{|c|}{$\begin{array}{l}\text { p-Value for Equality of } \\
\text { Average Marginal Effects }\end{array}$} & 0.491 & 0.387 & 0.648 \\
\hline
\end{tabular}

*This table shows, for each age category (graduated more than ten years ago and graduated less than ten years ago), the sum of the main effect of a given financial aid variable and the coefficient on the interaction between the financial aid variable and the age dichotomous variable. Coefficients for older alumni that are significantly different from the corresponding coefficient for younger alumni are italicized. Coefficients significant at the 5 percent level are marked with **, while those significant at the 10 percent level are marked with *. 